\title{
Treatment and utilization of liquid communal waste in the cities
}

\author{
Elena Vialkova ${ }^{1, *}$, Marina Zemlyanova ${ }^{1}$, and Anastasia Fugaeva ${ }^{1}$ \\ ${ }^{1}$ Industrial University of Tyumen, 625001, Volodarskogo str., 38, Tyumen, Russia
}

\begin{abstract}
Treatment and further utilization of wastewater sludge are the important city service problem. The paper presents an efficient method of super high frequency irradiation for communal liquid waste such as wastewater sludge. The effect of microwaves on the properties of sediments, including the outlet of heavy metal ions in to water, is shown. Technical and economic indexes and results of experimental researches, indicating the opportunities of microwave irradiation in processes of sediments heating, are presented. The influence on sludge temperature of some technological SHF parameters has been studied. Because of statistic analyze, a regression polynomial equation describing the heating of sludge mixture has been obtained. The microwave and electro thermal processing of municipal liquid waste taken from a city's wastewater plants have been compared. Energy efficient economy of microwave irradiation using for municipal wastewater sediments have been confirmed.
\end{abstract}

\section{Introduction and review}

In the South of the Tyumen region (Russia), the main sources of pollution of surface water bodies are enterprises of housing and communal services, industry and agriculture. The volume of regional wastewater is an average of about 314 million cubic meters per year. According to data for 2013-2016, on average $25-27 \%$ of wastewater is untreated at all. The largest amount of wastewater discharged falls on the industrial city Tyumen. There is about 280 million cubic meters per year (it is $90 \%$ of the total wastewater discharge) [1-3].

One of the key problems is the lack of new technologies and equipment for effective and resource-saving disposal of sewage sludge. The sludge utilization is quite serious task for cities municipal services. Only 10-15 percent of all sediments are able to treat by effective methods [1].

As a result, the growth of annual volumes of municipal liquid waste was recorded. The amount of forming wastewater sludge in the cities is presented on the Figure 1. For example, about 219,000 cubic meters of sludge and 10,950,000 cubic meters of activated silt are generated annually at the Wastewater Treatment Plant (WWTP) in the Tyumen city [3].

Wastewater precipitates are saturated with pathogenic bacteria and organisms, including eggs of helminths. Moreover, because of poor-quality treatment of industrial wastewater,

* Corresponding author: vyalkova-e @ yandex.ru 
sediments contain heavy metal ions in concentrations exceeding the normatively established values [1,4]. Recently it note, a huge number of technogenic pollutants are released into the environment from liquid municipal waste [4].

Traditional methods for collecting rainfall are as follows: compaction, aerobic and anaerobic digestion, reagent treatment, composting, natural and mechanical dehydration [1,4-7]. Less commonly used electro-thermal drying, thermal heating and burning [5,6]. New methods of communal liquid waste treatment are considered, including the process by electromagnetic radiation in the microwave range $[2,3]$.

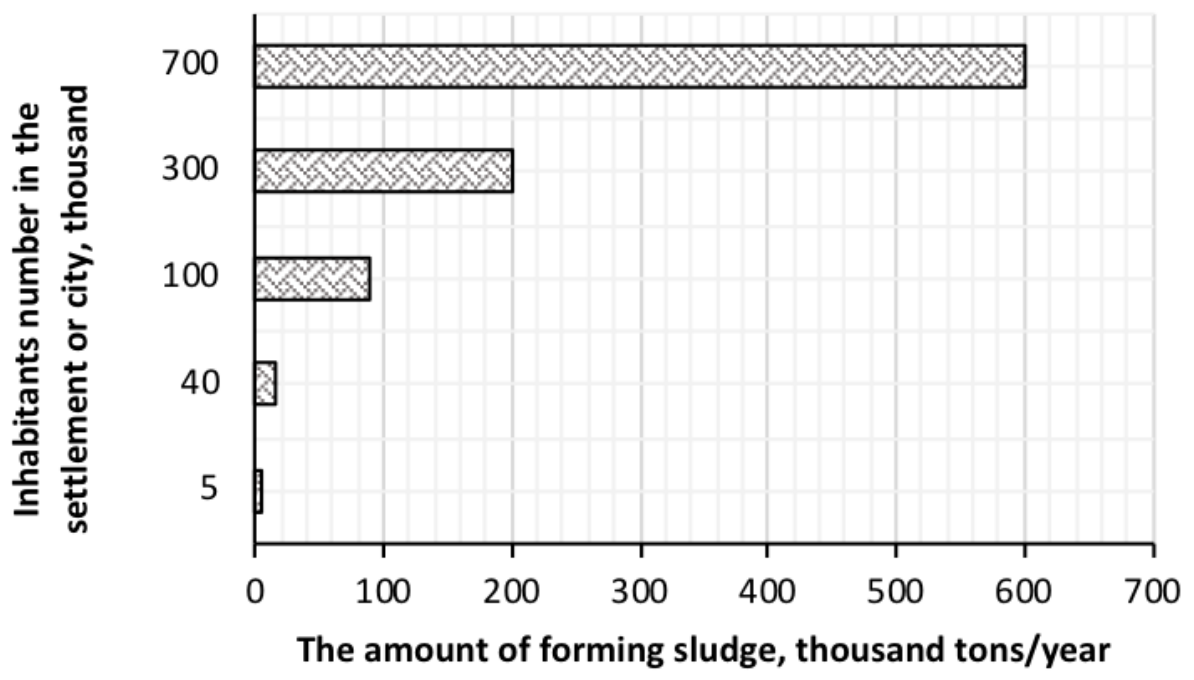

Fig.1.The amounts of forming wastewater sludge in the cities.

Municipal wastewater is the mixture of domestic, industrial and surface runoff sewage. The main goal of wastewater treatment is to safe discharge into the environment and for recycling purposes. Wastewater sludge tends to accumulate ions of heavy metals such as $\mathrm{Zn}, \mathrm{Cu}, \mathrm{Ni}, \mathrm{Cd}, \mathrm{Pb}, \mathrm{Hg}$ and $\mathrm{Cr}$. Havy metals content is restricting the use of sludge for agricultural purposes $[4,5]$.

The sludge origin and technological schemes of treatment affect the sewage sludge composition and its metals content. It is famous fact that the sewage sludge is mainly disposed of in special landfills and even into the seas. However, huge space of existing landfills and their environmental problems such as groundwater pollution from landfill leachate, odor emission and soil contamination have urged further investigation on various utilization ways [5,7].

One way of municipal sludge salvaging is usage as a raw material. Sewage sludge ash (SSA) is a waste obtained from the incineration of wastewater sludge. An investigation has been carried out to study the use of SSA in cement based construction materials [6].

One of the new ways of microwave (or SHF) usage is a irradiation of domestic wastes with the goal of their further recycling. Some ways in the sphere of liquid and solid municipal waste with the usage of electromagnetic microwaves radiation are offered [8-19].

Many researchers of microwave radiation note its thermal and non-thermal effects [1719]. Thermal effect is considered as an integral increase in the temperature of the sludge under SHF irradiation. The non-thermal theory explain the transition of electromagnetic energy in the energy of the molecular resonance depletion, photochemical reactions, and other species. This SHF additional effect gets advantages over traditional heating and can be used in technologies for processing of liquid municipal sludge. [11, 17-19] 
There is known microwave reactor ATON (Poland) for treatment of asbestos-cement wastes, which works in Europe and USA. In the treatment process, the waste mass reduces on 75-99 percent [2].

The way of industrial liquid waste disinfection in impact electromagnetic facility is known [9]. It was studied the proteins hydrolysis by microwave with a low irradiation capacity [10]. The compare results of convection heating research and heating by means of SHF-heating of industrial sewage sludge were obtained [11]. The microwave treatment of active silt makes the essential grow of its sedimentation rate and compaction degree [12]. The microwave treatment of sludge allows providing with effective removal of ions heavy metals [13]. The disinfecting of active silt's briquettes in microwave ovens is offered [14].

New microwave reactor is annually able to treat near one hundred thousand tons of solid domestic waste. There is special camera where SHF radiation and fuel gas decompose the waste [15]. Electromagnetic super high frequency radiation in semi-industrial reactors with processing power of 900-1200 W was applied to the dehydration and disinfection of municipal waste $[16,20]$.

\section{Description of studies}

Research of some sludge properties under microwave irradiation are presented. There were samples of raw sediments and activated silt in a 1:2 ratio from mechanical dehydration workshop at the Tyumen Wastewater Treatment Plant.

Several advantages of sludge microwave irradiation are observed. The adhesion of sediments to the walls of laboratory cylinder is significantly reduced. The high degree of decontamination is achieved. The outlet of heavy metal ions from sludge into the water increases from 4 to $15 \%$, especially lead, zinc and chromium (Table 1).

Table 1. Heavy metal ions content in wastewater sludge.

\begin{tabular}{|l|c|c|}
\hline $\begin{array}{c}\text { Heavy metals } \\
\text { ions }\end{array}$ & $\begin{array}{c}\text { Concentration } \\
\text { before treatment, } \\
\mathrm{g} / \mathrm{m}^{3}\end{array}$ & $\begin{array}{c}\text { Concentration } \\
\text { after SHF } \\
\text { treatment, } \mathrm{g} / \mathrm{m}^{3}\end{array}$ \\
\hline Mercury & 0.14 & 0.15 \\
\hline Lead & 35.42 & 41.99 \\
\hline Zinc & 145.00 & 151.00 \\
\hline Nickel & 19.43 & 20.68 \\
\hline Chromium & 25.21 & 29.75 \\
\hline
\end{tabular}

The maximum SHF treatment time of sludge samples before reaching the boiling point has been determined experimentally. The procedure and conditions for experiment were as follows: 1) Sampling of sludge mixture has been done. The sample volumes of sludge (V) were 50,100,150, 200 and $300 \mathrm{ml}$. 2) The initial temperature of the samples $\left(+20^{\circ} \mathrm{C}\right)$ has been measured. 3) It has been carried out by heating in a microwave oven with different installed power (W) 1000, 600 and $200 \mathrm{~W}$. 4) The start time of the sample boiling process has been measured by a stopwatch.

Based on the experience results, the graphs of the dependence $t=f(V)$ at a constant microwave power are shown (Fig. 2).

It is obvious that the higher the microwave processing power, the faster the sludge samples reach the boiling point. The fact has been established that heating rate of sludge at a microwave power of $200 \mathrm{~W}$ is $3.7-4$ times less than at a microwave power of $1000 \mathrm{~W}$ and it is 3-2.8 times less than at a microwave power of $600 \mathrm{~W}$. At the same time, the sludge heating at a power of $1000 \mathrm{~W}$ is 1.2 times more effective than heating at a power of $600 \mathrm{~W}$. 


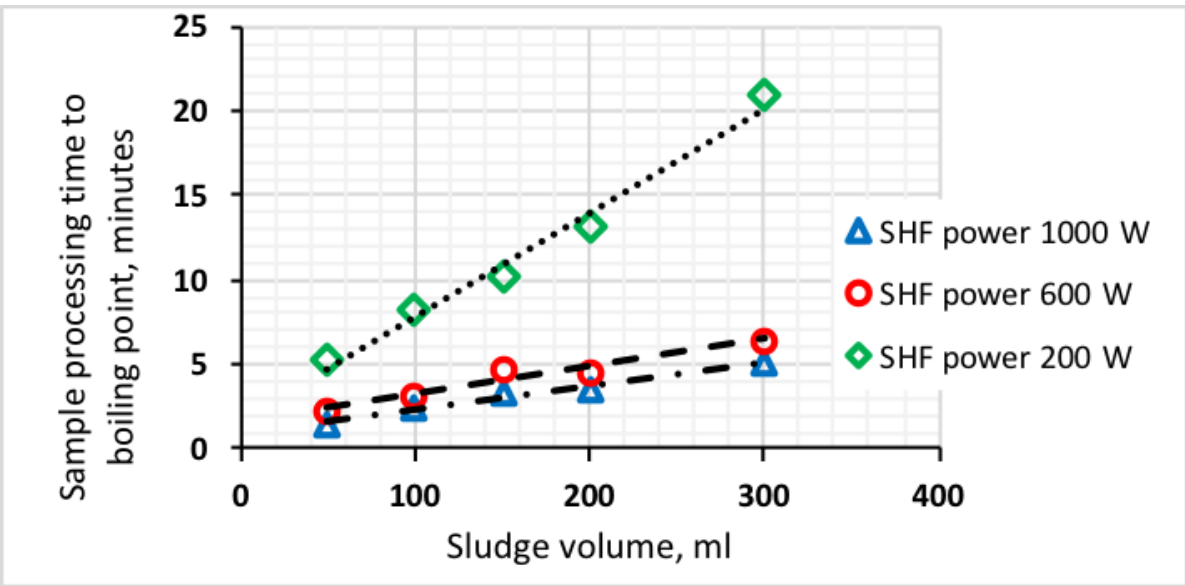

Fig. 2. There is dependence of the boiling time of a sludge mixture on the sample volume at a constant SHF capacity.

The effect on samples temperature (T) of the volume (V), microwave power (W) and the heating time (t) has been studied. As a result, a regression equation of first order polynomial type has been obtained. After removing the unimportant coefficients the equation in encoded form, it looks like this:

$$
T=54,35+12,23 \cdot \mathrm{W}-4,69 \cdot \mathrm{V}+18,27 \cdot \mathrm{t}-1,56 \cdot \mathrm{W} \cdot \mathrm{V}+6,90 \cdot \mathrm{W} \cdot \mathrm{t}-1,56 \mathrm{~V} \cdot \mathrm{t}
$$

During the analysis of the received regression, it's quite high adequacy has been confirmed. Analyzing the dependence obtained from the point of view of the influence of each of the factors, it has been found out that the dependence of the heating power and the processing time is directly proportional to the heating sludge temperature. The temperature of sediment samples is inversely proportional to the volume: the larger the sample volume, the more slowly the sediment is heated, other things being equal.

A comparison of two ways for heating sludge samples in a volume of $200 \mathrm{ml}$ has been made. There were microwave irradiation and ordinary electric heating of samples.

The experiences order and condition were as follows: 1) The start temperature of the samples has been measured (it was $+20^{\circ} \mathrm{C}$ ). 2) The heating of the first sample was made in a microwave oven of industrial design with an installed power of $600 \mathrm{~W}$. The temperature has measured by thermometer. 3) The second sample has been heated on an electric stove. During the experiment, the thermometer with a minimum division of 0.5 degrees has used for the fix of the temperature of the heated samples.

Based on the measurement results, a function plots $\mathrm{T}=\mathrm{f}(\mathrm{t})$ for two methods have been designed (Fig. 3). This process is presented with account of the constant microwave power $(\mathrm{W}=600 \mathrm{~W})$, the constant heat capacity of the electric plate, and for the constant sample volume $(\mathrm{V}=200 \mathrm{ml})$. 


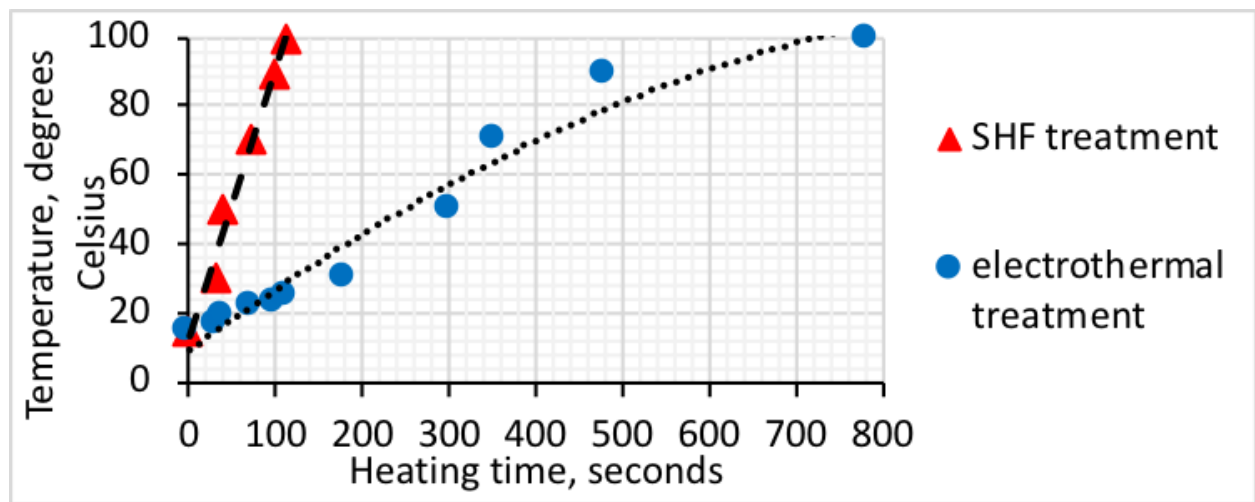

Fig. 3. There is dependence of the sludge temperature on the heating time of samples.

Because of obtained data comparison, it was found out that the heating time by the microwave method is 3.8-4 times faster than the usual electrothermal method. In addition, the sludge sedimentary properties after microwave heating by $10-15 \%$ better than for heated precipitations in the usual way. At the same time, electric power consumption for microwave heating is 2-2.5 times lower.

\section{Discussion}

The preliminary economic account of resource costs with using of main parameters have been done. The advance comparison of sewage sludge treatment's costs (euro per year) is shown on the Figure 4.

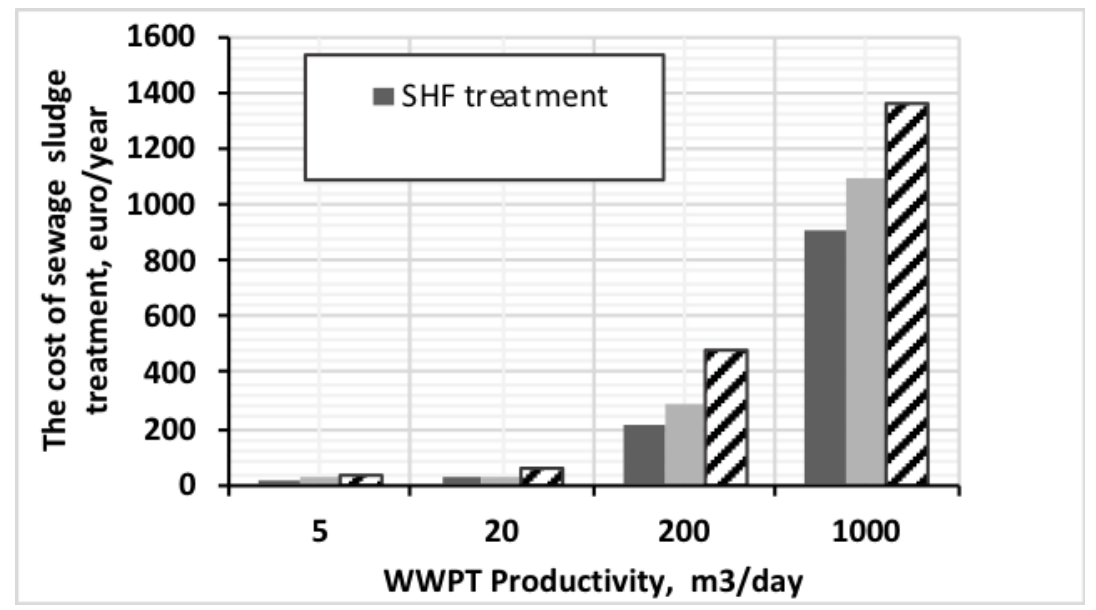

Fig. 4. The comparison of costs of sludge treatment kinds.

For Wastewater Treatment Plants with small and middle productivities the electrothermal method more expensive than electromagnetic treatment of sludge (approximately on 30-35\%). Also the sediment treatment with flocculants more expensive (on 15-20\%). In this case, the application of microwave irradiation of the precipitate is more advantageous than the use of traditional reagents. 


\section{Conclusion}

Research have shown under electromagnetic irradiation the wastewater sludge properties are changed significantly. The water content, concentration of metal ions and pathogenic bacteria's are decreased. The heating speed of sediments under microwave irradiation is higher than the usual convectional heating. The influence on sludge temperature of microwave parameters has been studied. Moreover, the regression polynomial equation describing the heating process has been obtained. In the process of studying, it has been found out that the using of SHF treatment at Wastewater Treatment Plants stations with a small or middle productivity is more economic advantageous than the use of convectional preheating and reagents.

\section{References}

1. V. Kichigin, E. Palagin, Obrabotka i utilizatsiya osadkov prirodnykh i stochnykh vod (SGASU, Samara, 2008).

2. E. Vialkova, M. Zemlyanova, A. Pesheva, Ecology \& Safety, 10, 121 (2016)

3. M. Zemlyanova, E. Vialkova, Trudy II Vserossiyskoy nauchnoy konferentsii s mezhdunarodnym uchastijem "Vodnyye i ekologicheskiye problemy Sibiri Tsentral'noy Azii" Barnaul, 1, 144 (2014)

4. E. M. Golet, I. Xifra, H. Siegrist, A. C. Alder, und W. Giger, Environmental Science \& Technology, 37 (15), 3243 (2003)

5. S. C. Chin, D. S. Ing, A. Kusbiantoro, Y. K. Wong, and S. W. Ahmad, ARPN Journal of Engineering and Applied Sciences, 11 (4), 2242 (2016)

6. V. Sahu, P. Sohoni, N. Dave and I. Verma International Journal of Engineering Science and Technology, 5(02), 242 (2013)

7. R. Uma Rani, Waste Management, 33, 1119 (2013)

8. S. Dovgan', Ekologiya i promyishlennost Rossii, 5, 28 (2012)

9. V. Tyagi, S. Lo, Renewable and Sustainable Energy Reviews, 18, 288 (2013)

10. T. Komarova, Ecologicheskiye sistemy i pribory, 48 (2013)

11. I. Gaponenkov, O. Fedorova, Vestnik MGTU, 16, 681 (2013)

12. V. Kapustin, A. Korzhavy, Sostoyaniye i okhrana okruzhayuchey sredy v Kaluge. Informatsionny obzor, 42 (2009)

13. V. Senkus, B. Stefanyuk, V. Senkus, S. Chasovnikov, I. Gridasov, A. Bogatyrev, N. Konakova, A. Kisel, Patent RU 2431510 C2, MPK CO2F 9/12, (2011)

14. A. Laptev, I. Abdullin, R. Akhiyarov, D. Bugay, O. Latypov, Sposob antibacterial'noy obrabotki potoka zhidkoy sredy, Patent RU 2376247 C2, MPK CO2F1 / 48, (2006)

15. S. Gunich, E. Yanchukovskaya, N. Dneprovskaya, Proceedings of Universities. Applied Chemistry and Biotechnology, 7, 183 (2017)

16. S. Mehdizadeh, C. Eskicioglu, J. Bobowski, T. Johnson, Water research, 47, 5040 (2013)

17. T. Zou, H. Li, N. Zhao, C. Shi, Journal of Alloys and Compounds, 1, 22 (2010)

18. G. Sapunov, Mikrovolnovyie pechi, http://www.elremont.ru/svch/bt_rem19.php.

(2007)

19. M. Watanabe, X. Qi, T. Aida, R. Lee Smith, Jr. "The Development and Application of Microwave Heating", book edited by Wenbin Cao, (2012) 
20. L. Obukhov, E. Vialkova, M. Zemlianova, Patent RU 2569533 C1, MPK CO2F 11/00, CO2F1 / 30, (2015) 